\title{
Соціологія
}

DOI: $10.15421 / 172070$

УДК: 316.33

\section{Transborder Cooperation in the Carpathian and Barents Regions: Optimization of Management through Comparative Sociological Analysis}

\section{Olesia Benchak, Uzhhorod National University}

The article is devoted to analysis of the peculiarities of transborder cooperation in the Carpathian and Barents regions and optimization of its management through comparative sociological analysis. The institutional capacity of managing transborder cooperation, in the Barents region of northern Europe, its focus on increasing human capital and reorienting to cluster development can serve as an example for the development of cross-border cooperation in the Carpathian region. This is evidenced by the multifaceted activities of the Barents Euro-Arctic and Barents Regional Councils for the development of cooperation between the border regions and territorial communities, coordination of priorities and implementation of Barents Co-operation programs at the international, intergovernmental and interregional levels, synchronization of their activities in the Arctic region with EU institutions, cooperation leading international structures in Northern Europe, the Arctic and the Baltic. Such institutional experience in the Barents region indicates the feasibility and high potential impact of establishing a new multilateral international instrument for supporting crossborder cooperation in the Carpathian region. This experience should not be copied, but should be implemented taking into account the specifics of the Carpathian region. The author's position on the methodological foundations of the sociological study of crossborder interactions as a differentiating and solidarizing factor is formulated. Perspective directions of research of cross-border interactions are seen first of all in: creation of international research collectives; elaboration and improvement of sociological tools for monitoring the state and dynamics of cross-border interactions; constructing a system of indicators that characterize the factors of micro, meso, macro and global levels that determine the content of cross-border interactions. The Ukrainian-Slovak, Ukrainian-Hungarian and Ukrainian-Romanian borders as a special space of social differentiation and integration remain extremely unexplored.

Keywords: transborder cooperation comparative sociological study, crossborder interactions, system approach in research of crossborder interactions

\section{Транскордонне співробітництво в Карпатському і Баренцевому регіонах: оптимізація управління за допомогою порівняльного соціологічного аналізу}

\section{Олеся Бенчак, ДВНЗ «Ужгородський національний університет»}

Стаття присвячена аналізу особливостей транскордонного співробітництва в Карпатському і Баренцевому регіонах і оптимізації управління ними за допомогою порівняльно-соціологічного аналізу. Інституційний потенціал управління транскордонним співробітництвом у Баренцевому регіоні Північної Свропи, його орієнтація на збільшення людського капіталу та переорієнтація на кластерний розвиток може служити прикладом для розвитку транскордонного співробітництва в Карпатському регіоні. Про це свідчить багатогранна діяльність Ради Баренцева/Евроарктичного і Баренцевого регіонів з розвитку співпраці прикордонних регіонів і територіальних громад, узгодження пріоритетів і реалізація програм Баренцевого співробітництва на міжнародному, міжурядовому та міжрегіональному рівнях, синхронізація їх діяльності з інститутами ЄС в Арктичному регіоні, співпраця провідних міжнародних структур у Північній Свропі, Арктиці і Балтії. Такий інституційний досвід у Баренцевому регіоні вказує на високий потенціал багатостороннього міжнародного 
інструменту для підтримки транскордонного співробітництва в Карпатському регіоні. Цей досвід може бути впроваджений з урахуванням специфіки Карпатського регіону. Сформульована авторська позиція щодо методологічних засад соціологічного дослідження транскордонних взаємодій як фактора, який диференціює та солідаризує. Перспективні напрямки дослідження транскордонних взаємодій вбачаються в першу чергу в: створенні міжнародних дослідницьких колективів; розробці та вдосконалення соціологічного інструментарію для моніторингу стану і динаміки транскордонних взаємодій; побудові системи показників, що характеризують фактори мікро, мезо, макро і глобального рівня, що визначають зміст транскордонних взаємодій. Названий інструментарій може, зокрема, бути застосований у вивченні українсько-словацького, українсько-угорського та українсько-румунського транскордонного співробітництва та пограниччя як особливого простору соціальної диференціації і інтеграції.

Ключові слова: порівняльне сочіологічне дослідження транскордонного співробітництва, транскордонні взаємодії, системний підхід у дослідженні транскордонних взаємодій

\section{Трансграничное сотрудничество в Карпатском и Баренцевом регионах: оптимизация управления посредством сравнительного социологического анализа}

\section{Олеся Бенчак, ИГВУЗ «Ужгородский национальный университет»}

Статья посвящена анализу особенностей трансграничного сотрудничества в Карпатском и Баренцевом регионах и оптимизации управления ими посредством сравнительно-социологического анализа. Институциональный потенциал управления трансграничным сотрудничеством в Баренцевом регионе Северной Европы, его ориентация на увеличение человеческого капитала и переориентацию на кластерное развитие может служить примером для развития трансграничного сотрудничества в Карпатском регионе. Об этом свидетельствует многогранная деятельность Совета Баренцева/Евроарктического и Баренцева регионов по развитию сотрудничества приграничных регионов и территориальных сообществ, согласование приоритетов и реализация программ Баренцева сотрудничества на международном, межправительственном и межрегиональном уровнях, синхронизация их деятельности с институтами ЕС в Арктическом регионе, сотрудничество ведущих международных структур в Северной Европе, Арктике и Балтии. Такой институциональный опыт в Баренцевом регионе указывает на осуществимость и высокий потенциал многостороннего международного инструмента для поддержки трансграничного сотрудничества в Карпатском регионе. Этот фопыт может быть внедрен с учетом специфики Карпатского региона. Сформулирована авторская позиция о методологических основах социологического исследования трансграничных взаимодействий как дифференцирующего и солидаризирующего фактора. Перспективные направления исследования трансграничных взаимодействий видятся в первую очередь в: создании международных исследовательских коллективов; разработке и совершенствовании социологического инструментария для мониторинга состояния и динамики трансграничных взаимодействий; построении системы показателей, характеризующих факторы микро, мезо, макро и глобального уровня, определяющие содержание трансграничных взаимодействий. Названный инструментарий может, в частности, быть использован в изучении украинско-словацкого, украинско-венгерского и украино-румынского трансграничного взаимодействия и пограничья как особого пространства социальной дифференциации и интеграции.

Ключевые слова: сравнительное сочиологическое исследование трансграничного сотрудничества, трансграничные взаимодействия, системный подход в исследовании трансграничных взаимодействий 
$\mathrm{C}$ ontemporary transborder cooperation is a very powerful and, importantly, a constructive resource for development of the international relations system. Active cooperation has a positive effect on solving the problems of participating cross-border regions, creates conditions for accelerated growth of welfare, directs partner countries policy towards equalizing level of life between more developed and depressed and peripheral regions.

This is confirmed by development of transborder cooperation in the geopolitical area of the Carpathians. European Union enlargement has opened up entirely new opportunities for its expansion and deepening.

However, analysis of the issues of transborder cooperation dynamics (hereinafter - TBC) in this important part of Europe shows that its management requires significant optimization. In particular, currently there is an urgent need in using such efficient management tools as:

- macro policy coordination,

- state economic incentives;

- bilateral and multilateral financial cooperation (Ustych, 2007).

In the early $90 \mathrm{~s}$ of the last century the first in Central and Eastern Europe Euroregion was set up, titled the Carpathian Euroregion. During a decade this association of border cooperation of neighboring regions of Hungary, Poland, Slovakia, Romania and Ukraine had been developing very well and was even considered a reference for the European TBC.

Over time, however, and especially at the beginning of this century, it began to fade. It is regrettable for one of the authors of these lines to state this because he was one of the initiators of the Carpathian Euroregion and the first Chairman of the Council of this organization from Ukraine. The current deep crisis of this international structure can be evidenced by the fact that the joint authority of heads of border regions members of the Carpathian Euroregion - its Council - in fact ceased to exist (Benchak, 2017a).

But we know that the Carpathian Euroregion was set up by the Foreign Affairs Ministers of the member countries by signing the relevant Declaration. Therefore, it would seem that in the present crisis situation of the Euroregion its macro-policy guarantors should be intervening to help him overcome existing transformational development obstacles. But very strange is the fact that since its inception in 1993, not one ministerial meeting devoted to its problems took place.

So which support and coordination by governments for this very important regional organization one can speak about (except for the ceremonial mentioning of the importance of its existence, coming out easily every now and then at official meetings)?

Currently there exists and institute of intergovernmental commissions on transborder cooperation. However, experience shows that their activity is quite bureaucratic and lacks efficiency. For example, the latest annual (2016) meeting of the Ukrainian-Slovak Commission resulted in no joint protocol agreed.

In addition, commissions deal with transborder cooperation issues only at the bilateral level, not sufficient for solving complex, multi-stakeholder problems of the region.

Governments on both sides of the new Eastern border seem to be active in transborder cooperation programs. But a careful study of the real situation reveals that in fact they perform rather go-between and regulatory functions in the allocation of funds coming from the budget of the European Union and other countries of the continent according to special platforms (European Union ENPI and ENI, Norwegian financial mechanism, etc.) They can in some way participate in their cofinancing if this is conditioned by the donor.

In terms of their own their bilateral or multilateral intergovernmental transborder cooperation programs with appropriate funding, at the new Eastern border in the Carpathian they are unfortunately non-existant. This negatively affects activities if transborder structures that are not able to get a financial backing from the European funds. The fate of the Carpathian Euroregion is a dramatic confirmation (Ustych, 2014).

Apparently, cross-border cooperation in the area of the Carpathians in general, and Ukrainian-Slovak TBC in particular lacks effective tools of macropolitical coordination and support.

Meanwhile, such tools in Europe are existing, and there is a vast positive experienced accumulated in its use. One particular example can be found in the North of our continent (Espiritu, 2015).

Significance of the macropolitical tools for the TBC development is evidenced by more than twenty years operation of North European 
institutions, in particular of Euro-Arctic Council and of the Regional Council (established in 1993).

Barents Euro-Arctic Council is the organ of the Foreign Affairs Ministries of Norway, Sweden, Finland, Iceland, Denmark, European Commission and Russia. It provides efficient macropolitical support and transborder cooperation management in the Barents region (Flikke, 2010).

The Council of the Barents Euro-Arctic Region was established on the initiative of Norway, supported by Russia and Finland. The main motive of the member countries of the Council including Denmark, Iceland, Norway, Russia, Finland and Sweden, and the representative of the European Union (nine more countries have observer status) has been striving to maintain the centuries-old commitment of the Barents region peoples to neighborliness and cooperation, it environmental development and exploration of natural resources, creation of more comfortable and decent human living conditions. This meant that BEAC would not replace or duplicate the work already carried out on a bilateral or multilateral operation between member states, but it will promote the development of regional cooperation.

The concept of the Barents Cooperation was formulated in Kirkenes Declaration of October 11, 1993 (The Kirkenes declaration, 1993). It defines the main directions of cooperation in the field of economy, transport and communications, cultural relations and peopleto-people contacts, scientific and technical cooperation, environment. The Declaration contains references to legislation, such as the European Energy Charter, the Convention on Environmental Impact Assessment (EIA Convention) and some agreements and strategies for environmental protection of the Arctic region. These laws and strategies have become an important foundation for future initiatives of cross-border cooperation. They helped to create a reliable legal framework for cooperation.

The Kirkenes Declaration of 1993 clearly determined that this regional cooperation should be considered as a contribution to the security of the whole of Europe. Reflecting a new frame of reference for European security, the Declaration emphasizes inter alia: "The participants expressed their conviction that expanded cooperation in the Barents EuroArctic Region would contribute substantially to stability and progress in the area and in Europe as a whole. The confrontation and division that characterised the past would be replaced by cooperation and partnership. The parties believed that such cooperation would contribute to international peace and security" (Bailes, Herolf, Sundelius, 2006).

Regarding the institutional framework of cooperation, the Declaration laid out principles of alternating presidency of the member countries' ministries. The supreme body of the Council is the annual session of the foreign ministers of the participating countries, decisions on which are taken by consensus. In addition, "industry" sessions of ministers and heads of central agencies of member countries of the areas of cooperation take place, as well as meetings of the Committee of Senior Officials of cooperation that performs the functions of operational management.

Two-level institutional system is composed of the Regional Council, which works at the regional level, and the Council of Foreign Ministers on the political level.

As for the structure and property, the organization of executive and administrative body - the Secretariat is quite specific to the region.

Barents Regional Council is an institution of heads of border regions of Norway, Sweden, Finland and Russia. It provides a systematic and tight cooperation of border areas in solving common problems of TBC (Holm-Hansen, Aasland, Dybtsyna, 2008).

International Barents Secretariat is a standing technical body dealing with proper organizational support of multilateral transborder cooperation. Its office is located in the Norwegian town of Kirkenes.

The Norwegian Barents Secretariat is a permanent executive and administrative body, coordinates transborder cooperation of the northern provinces of Norway: Nordland, Troms and Finnmark with partners in neighboring countries and funded by the Ministry of Foreign Affairs and other ministries of Norway, which allocate funds for special grant programs in the areas of regional development, health, culture etc.

Activities of these institutions are based on a new philosophy of transborder relations in the Barents Sea basin, proposed in the early 
90-ies by the outstanding statesman, Norwegian Foreign Affairs Minister Thorvald Stoltenberg (Stoltenberg, 2009). Fundamentals of this philosophy include pragmatism and mutual understanding.

The fundamental principles of the Barents Euro-Arctic Council, Regional Council and the International Barents Secretariat functioning include:

1. Consensus decision-making.

2. Equal cofinancing on the basis of minimized costs.

3. Asynchronous rotation of presidency (for 2 years).

4. Activities of the presiding country are based on the biennial program approved by partners.

5. The program is implemented through the operation of specialized international working groups.

According to estimates of the European Commission, the Barents Euro-Arctic Council and the Regional Council are successful specialized international regional organizations. This assessment, in particular, was made at a conference aimed at studying the northern experience of transborder cooperation held in Brussels in 2015.

Slovak, Ukrainian and Norwegian experts in November 2016 participated in the study of the northern experience of crossborder cooperation within the framework of the successful implementation of the project "Through Innovation - for Effective Cooperation" ("Information provision and implementation of innovative approaches to cross-border cooperation between Slovakia and Ukraine") funded by a grant from the Norwegian kingdom with the help of the Norwegian Financial Mechanism and co-financed from the state budget of the Slovak Republic (Through innovations to effective cooperation, 2016) .

The project "Information provision and implementation of innovative approaches to cross-border cooperation between Slovakia and Ukraine" (CB 01030) provides that scientific analysis of economic, financial and organizational aspects in the activity of such international organizations as the Barents Euro-Arctic Council (BEAC) and the Barents Regional Council (BRC) should be a reliable basis to implement the Scandinavian practices both in terms of international cooperation of regions and local communities of the Slovak Republic and Ukraine, and in a wider context throughout the whole space of interaction and cooperation of transboundary regions and communities of these and other countries in the Carpathian region.

The aim of the project was:

a) obtain and analyze authentic, high-quality and complete information on the forms, methods and results of the Barents Euro-Arctic Council and the Barents Regional Council activity ;

2) development for the managing authorities of Slovakia and Ukraine of the practical recommendations on its implementation to improve the efficiency of transborder cooperation between border regions of these countries, in particular, and in the Carpathian region in general;

The project team set themselves the task of systematic study of the Barents Euro-Arctic Council and the Regional Council activities. First, they sought to uncover the basic context of regional cooperation in the Barents Arctic region, incorporating complex problems of Northern Europe and the Arctic region. Researchers did not stop at certain theories of regionalization or at general system of perception of regional cooperation in a globalized world.

Emphasis was placed on the structure and function - two characteristics, the quality of which can contribute to the expansion of effective cooperation, including in the broader system of international and political relations.

The Barents Euro-Arctic Council and Regional Council are institutions of Northern states and the EU, aimed at promoting crossborder cooperation in the Barents region. They were created in the early 90 -ies on the initiative of prominent Scandinavian politician - then Foreign Minister of Norway Thorvald Stoltenberg (and father of the current NATO Secretary General Jens Stoltenberg). Despite his age, Thorvald Stoltenberg until now is keenly interested in issues of European cross-border cooperation, and he was one of the initiators of the above project development.

The program of their stay in the Norwegian border town of Kirkenes was very busy.

Ukrainian experts had a meeting with the leaders of the Barents Institute - a unit of the Norwegian Arctic University in Tromso that deals with research on cross-border cooperation, where collaborative developments 
and publications by scholars were discussed between Norwegian Arctic University in Tromse, Uzhhorod National University and Safarik University in Kosice, exchange of students and teachers for internships.

Productive meetings took place with the structures that provide activities of the Barents Euro-Arctic Council and the Regional Council - the Norwegian Barents Secretariat and the International Barents Secretariat. The first structure is part of the Ministry of Foreign Affairs of Norway, located in Kirkenes and coordinating cross-border cooperation in the region. The International Barents Secretariat is an intergovernmental structure for interaction with Nordic partners and the EU in the development of crossborder cooperation (Karlsbakk, 2010).

In general, the working trip of experts to Norway allowed to explore the latest and most effective forms of cross-border cooperation practiced in the North of Europe (Benchak, $2017 \mathrm{~b}$ ). It is a good guarantee of the achievement of the objectives set by the project "Through innovation - to effective cooperation".

After the successful implementation of the project there were made the presentations of the materials for the project "Information provision and implementation of innovative approaches to cross-border cooperation between Slovakia and Ukraine:

- on the meeting with the Extraordinary and Plenipotentiary Ambassador of Norway to Ukraine - Ole Terje Horpestad (September 22, 2017) in Uzhhorod (Visit of, 2017);

- on the meeting with the Ambassadors of the Visegrad countries in Uzhhorod on October 7-th, 2017. The meeting was attended by Extraordinary and Plenipotentiary Ambassadors: Hungary in Ukraine - Erno Keshken, Slovak Republic - Juraj Sivacek, Poland - Jan Pieklo, Czech Republic - Radek Matula and members of delegations and Director of the Institute for Cross-Border Cooperation, Ambassador Extraordinary and Plenipotentiary, and Professor of the Uzhorod National University Serhii Ustych;

- On October 17-th, 2017 there was made a presentation in the Ambassy of Ukraine to Slovak Republic on the meeting with the Extraordinary and Plenipotentiary Ambassador of Ukraine to the Slovak Republic - Yurii Mushka.
- On October 26-28-th there was a presentation of the project in Tasnad city (Romania) on the 8-th International symposium "Ukrainian-Romanian relations: history and contemporary".

- On December 1-st, 2017 round table meeting of the Minister for Foreign Affairs of Ukraine P. Klimkin and scientists of Uzhhorod National University. The Expert of the project Volodymyr Prykhodko presented the results of the project "Information provision and implementation of innovative approaches to cross-border cooperation between Slovakia and Ukraine".

Conclusions. A comparative sociological analysis of cross-border cooperation is an important tool for improving the efficiency of cross-border cooperation. The search for innovative ways to enhance the SlovakUkrainian cooperation in the Carpathian region led Slovak and Ukrainian experts to in-depth analysis of developments in Norway and other Nordic countries of bilateral and multilateral transborder cooperation, that have been for a long term consistently implemented by Barents Euro-Arctic Council and the Regional Council in the format of Barents Cooperation.

In the course of the project, Ukrainian experts strengthened their belief that the institutional capacity of transborder cooperation management in the Barents Region of the Northern Europe, its focus on the "green economy" priorities, increase of human capital and shift to cluster development can serve as a model for the development of transborder cooperation between Slovakia and Ukraine in the Carpathian region. This is confirmed by multifaceted activities of the Barents EuroArctic and the Barents Regional Councils in promotion of cooperation among border regions and local communities, coordination of priorities and implementation of the Barents cooperation at the international, interstate and interregional level, synchronization of activities in the Arctic region with the EU institutions, leading structures of international cooperation in Northern Europe, the Arctic and the Baltic.

Why governing and advisory structures of the Barents Region, established the same time as the CarpathianEuroregion in 1993, fornearly aquarter of a century operate effectively and continuously, dedicated to combat cross-border and interstate, economic and ideological asymmetry, 
resulting in quite successful good examples of transborder cooperation compensation effect? This is the effect of the synergy of national and regional priorities, achieved by a two-tier system of governing bodies (intergovernmental and interregional level), operating on the principles of rotation and consensus, practical combination of manifestations of globalization and functional tasks ensured by professional international organization and personnel - international and Norwegian secretariat, flexible network of working groups on priority activities. A well-established funding of administrative activities and own funding instruments for transborder cooperation play a systematically important role in operation of institutions and implementation of programs.

Experts defined the context of Barents EuroArctic Region creation and its special regional cooperation function and practices in the Northern Region.

Regardless of its membership in the EU, the region is interconnected with other regional initiatives in the EU and is in this sense an important element of the EU neighborhood policy. In the new international environment, cooperation in the Northern region is not decisive in the sense of local identity, but plays a significant role at the functional level. Compared to many others, the Barents Sea region can be considered particularly successful in its activities of cooperation promotion through concrete projects. As for regional policy in Europe at large, the sub-regional efforts in the North could serve as a lesson for subregional initiatives elsewhere, including for the Visegrad countries and Ukraine.

Barents cooperation shows that:

- long-term bilateral problems should be formulated as common challenges for the management and sustainable development. This expands the significance of the paradigm that the states sometimes are too big to solve small problems or too small to solve big problems;

- practical issues should be addressed not through the lens of ideology, but rather in the viewpoint of practical results. Practical and functional dimensions of transborder cooperation are important not only as a tool, but also as a goal;

- we should stick to local characteristics. Regions are embedded into the system of relationships, but they also exist in their own legal system and are formed under specific characteristics of neighboring regions and contacts that are created over the centuries;

- regional cooperation is intended not to change priorities, but to change the attitude to borders and border regions. It is important to emphasize the differences between national priorities and global challenges. Globalization threatens national states, internationalization strengthens them. Good neighborly relations strengthen the ability of national states to governance.

Given all of the above, based on research of the Barents Euro-Arctic Council and the Regional Council activities, we believe we could formulate the most important practical recommendations for the subjects of transborder cooperation of all levels:

1. Recognize that Nordic experience of political support and coordination of transborder cooperation deserves a wider application in the Carpathian region.

2.Experience is not tobe copiedmechanically, but only selected, first of all institutional frameworks of transborder cooperation based on historical, mental, economic and political features of the Carpathian transborder region, shall be implemented.

3. Consider establishment of specialized international regional organizations (names can be specified):

- Carpathian Cooperation Forum - the body of the Ministries of Foreign Affairs of the participating countries - for macro policy support and transborder cooperation management.

- Carpathian Regional Forum - the body of border regions heads - for systematic and close cooperation of border areas to solve common problems.

- International Carpathian Secretariat - a permanent body of representatives from the participating countries - for organizational and technical support of multilateral transborder cooperation.

4. Propose the following geopolitical configuration of the participating countries from the mentioned institutions: Slovakia, Hungary, Romania, Poland, Czech Republic, European Commission, Ukraine (Benchak, 2017c).

Define the following criteria for the configuration: Basin. 
- location at the new eastern border of the European Union.

- historical kinship and current integrity.

5. In order to create these specialized international regional organizations, to initiate a Carpathian Summit of leaders from Slovakia, Hungary, Romania, Poland, Czech Republic, European Commission, Ukraine with the adoption of an appropriate "Declaration".

Of course, practical recommendations can and will be refined and specified.

In general, consideration of practices of the Scandinavian partners will enable to:

a) avoid overlapping and duplication in the development of European transborder cooperation;

b) improve the quality of cross-border cooperation in the Carpathian region, including more efficient and economical use of available resources (human, financial, material, time, etc.).

By creating and active operation of the offered in practical recommendations specialized institutions, additional opportunities can emerge for further intensification of bilateral relations of neighboring countries, especially in the Visegrad format, fostering real, not just declarative alignment of Ukraine with this very important European regional structure.

In the 1990s during significant geopolitical transformations, when transborder cooperation in Carpathian Euroregion played extremely positive role in establishing relations, trust building and conflict prevention between the states of the Central and Eastern Europe. Today, those states could pay back their "debt" to transborder cooperation by embracing its current transformation problems and helping to resolve them. In September 2018, Ambassador Extraordinary and Plenipotentiary of Poland to Ukraine Jan Pieklo, while in Transcarpathia, during the celebration of the Ukrainian-Polish Days of Neighborhood did not conceal his enthusiasm that after the 16-year-old break the tradition of holding the Ukrainian-Polish Neighborhood Day in Transcarpathia was restored. It is very important that this work will be continued and these Neighborhood Days in the Carpathian areal were restored.

The article is devoted to analysis of the peculiarities of transborder cooperation in the Carpathian and Barents regions and optimization of its management through comparative sociological analysis. The institutional capacity of managing transborder cooperation, in the Barents region of northern Europe, its focus on increasing human capital and reorienting to cluster development can serve as an example for the development of cross-border cooperation in the Carpathian region. This is evidenced by the multifaceted activities of the Barents Euro-Arctic and Barents Regional Councils for the development of cooperation between the border regions and territorial communities, coordination of priorities and implementation of Barents Co-operation programs at the international, intergovernmental and interregional levels, synchronization of their activities in the Arctic region with EU institutions, cooperation leading international structures in Northern Europe, the Arctic and the Baltic. Such institutional experience in the Barents region indicates the feasibility and high potential impact of establishing a new multilateral international instrument for supporting cross-border cooperation in the Carpathian region. This experience should not be copied, but should be implemented taking into account the specifics of the Carpathian region. Sociology plays an important role in understanding the nature and trends of crossborder processes. Prerequisites for the creation of a modern methodology for studying crossborder interactions are laid down by the developments in theoretical sociology such as post-classical metaparadigm, sociological constructivism, so-called "spatial turn" in social sciences, theory of sociology of mobility. The methodological principles of sociological research of transboundary processes, proposed should include: cognitive principle of genetic-functional analysis; focus on the practical achievement of transborder processes optimization; concentration on the organizational and managerial dimension of cross-border interactions; reliance on a wide range of research methods; analysis of expert and mass level of perception of cross-border interactions and their organizational support. Perspective directions of research of crossborder interactions are seen first of all in: creation of international research collectives; elaboration and improvement of sociological tools for monitoring the state and dynamics 
of cross-border interactions; constructing a system of indicators that characterize the factors of micro, meso, macro and global levels that determine the content of cross- border interactions. The Ukrainian-Hungarian and Ukrainian-Romanian borders as a special space of social differentiation and integration remain extremely unexplored.

\section{REFERENCES}

Bailes, A. J. K., Herolf, G., \& Sundelius, B. (2006). The Nordic Countries and the European Security and Defence Policy. Oxford: Oxford University Press.

Benchak, O. (2017a). Recommendations and proposals for increasing effectiveness of Slovak-Ukrainian crossborder cooperation and the model of its institutionalisation. Kosice: Centre of Social and Psychological Sciences of the Slovak Academy of Science, $12 \mathrm{p}$.

Benchak, O. (2017b). The study of the experience of the norwegian-russian and slovak-ukrainian cross-border cooperation. Kosice (Slovak republic): Centre of Social and Psychological Sciences of the Slovak Academy of Science.

Benchak, O. (2017c). Istoriya, shcho ob'yednuye. Narysy novitn'oyi transkordonnoho spivrobitnytstva $v$ Karpats'komu rehioni [A unifying history: essays on the latest cross-border cooperation in the Carpathians region]. S.Ustych (Ed.). Uzhhorod: DVNZ «UzhNU» [in Ukrainian].

Espiritu, A. A. (2015). Moving forward: Strengthening cooperation in today's Barenth Region. Barents Studies, 1, 7-11.

Flikke, H. (2010) Rehional'na spivpratsya v Pivnichnomu rehioni: yiyi znachushchist' i obmezhennya [Regional cooperation in the Northern region: its significance and limitations]. Proceedings of International Scientific Conference: Ukrayina $i$ Vyshehrads'kiy chetvirky: na shlyakhu do vzayemovyhidnykh vidnosyn - Ukraine and the Visegrad Four: on the way to mutually beneficial relations. Uzhhorod. (pp. 8-11). Retrieved from http://www.uk.x-pdf. ru/5mehanika/1246854-11-ukraina-vishegradska-chetvirka-shlyahu-vza-movigidnih-vidnosin-ukraina-vishegradskachetvirka-shlyahu-vza-movigidnih-vi.php [in Ukrainian].

Holm-Hansen, J., Aasland, A., \& Dybtsyna, E. (2008). Building Neighbourhood. Evaluation of the Barents Secretariat's grant programme, Norwegian Institute for Urban and Regional Research (4).

Karlsbakk, J. S. (2010). More cash to Barents projects. The Norwegian Barents Secretariat. Retrieved from http://www.barents.no/more-cash-to-barentsprojects.4762026-41098.html

Stoltenberg, J. (2009). Samtaler. Oslo: Aschehoug forlag.

The Kirkenes Declaration, Conference of Foreign Ministers on Co-operation in the Barents Euro-Arctic Region. (1993). Retrieved from http://www.unep.org/dewa/ giwa/areas/kirkenes.htm.

Through innovations to effective cooperation. (2017). Retrieved from http://www.cbcinnovations.sk/index.php/uk/

Ustych, S. I. (2007). Transkordonne spivrobitnytstvo yak al'ternatyva novomu «zaliznomu zavisi» ta konfliktam: Kompleksne doslidzhennya [Cross-border cooperation as an alternative to the new Iron Curtain and conflicts: A comprehensive study]. (pp. -58). Uzhhorod: Karpaty [in Ukrainian].

Ustych, S. I. (2014). Instytut transkordonnoho spivrobitnytstva, m. Uzhhorod (Ukrayina). Optymizatsiya transkordonnoy statystyky. Zbirnyk naukovykh prats' [Optimization of cross-border statistics. A collection of scientific works. Uzhhorod]. Uzhhorod [in Ukrainian].

Visit of Extraordinary and Plenipotentiary Ambassador of Norway to Ukraine. (2017). Retrieved from http://www.uzhnu.edu.ua/uk/news/v-uzhnu-vpershe-prijmali-kerivnika-diplomatichnoji.htm

\section{Бенчак Олеся}

Старший викладач

ДВНЗ «Ужгородський національний університет»

Email: olesia.benchak@uzhnu.edu.ua

\author{
Benchak Olesia \\ Senior Lecturer \\ Uzhhorod National University
}

ORCID: 0000-0001-7498-6077

Цитування: Бенчак, О. (2020). Транскордонне співробітництво в Карпатському і Баренцевому регіонах: оптимізація управління за допомогою порівняльного соціологічного аналізу. Науково-теоретичний альманах «Грані», 23 (8), 5-13. doi: 10.15421/172070

Citation: Benchak, O. (2020). Transborder Cooperation in the Carpathian and Barents Regions: Optimization of Management through Comparative Sociological Analysis. Scientific and theoretical almanac "Grani», 23 (8), 5-13. doi: $10.15421 / 172070$

Стаття надійшла / Article arrived: 01.09.2020

Схвалено до друку / Accepted: 03.10.2020 